INDONESIAN JOURNAL OF

Clinical Pathology and Medical Laboratory

Majalah Patologi Klinik Indonesia dan Laboratorium Medik

\begin{tabular}{|c|c|c|c|c|c|}
\hline $\begin{array}{c}\text { IJCP \& ML } \\
\begin{array}{c}\text { (Maj. Pat. Klin. } \\
\text { Indonesia \& Lab. Med.) }\end{array}\end{array}$ & Vol. 17 & No. 3 & Hal. 127-177 & $\begin{array}{c}\text { Surabaya } \\
\text { Juli 2011 }\end{array}$ & $\begin{array}{c}\text { ISSN } \\
0854-4263\end{array}$ \\
\hline
\end{tabular}

Diterbitkan oleh Perhimpunan Dokter Spesialis Patologi Klinik Indonesia

Published by Indonesian Association of Clinical Pathologists

Terakreditasi No: 43/DIKTI/Kep/2008, Tanggal 8 Juli 2008 


\section{INDONESIAN JOURNAL OF \\ CLINICAL PATHOLOGY AND MEDICAL LABORATORY \\ Majalah Patologi Klinik Indonesia dan Laboratorium Medik}

\section{DAFTAR ISI}

\section{PENELITIAN}

Creatine Kinase Myocardial Band, Myeloperoxidase, Matrix Metalloproteinase- 9 dan Troponin T Pada IMA

(The Creatine Kinase Myocardial Band, Myeloperoxidase, Matrix Metalloproteinase-9 Activities and Troponin $T$ in Myocardial Infarction)

IA Hutagalung, I Patellongi, R Pakasi, M Arif, AA Mappahya, Hardjoeno

D-Dimer Penderita Sindrom Koroner Akut dan Stenosis

(D-Dimer in Acute Coronary Syndrome and Stenosis)

Birhasani, Lisyani BS, Ria T

Uji Hematologi Pasien Terduga Demam Berdarah Dengue Indikasi Rawat Inap

(Hematology Test of Dengue Hemorrhagic Fever on Suspected Patients Indicated for Hospitalization) Juranah, Darwati Muhadi, Mansyur Arif, Burhanuddin Bahar .

Imunokimiawi PGE2 Usus Ileum yang Kekurangan Energi Protein

(Immunohistochemistry of PGE2 Ileum Intestine Protein Energy Deficiency)

R. Heru Prasetyo

Gamma-glutamyltransferase dan Apolipoprotein B dengan Sindroma Metabolik

(Gamma-glutamyltransferase and Apolipoprotein B with the Metabolic Syndrome)

Tahono, M.I. Diah Pramudianti.

146-150

Umbi Ubi Jalar Ungu Bali (Ipomoea batatas) di Transaminase Serum, Malondialdehide Hepar dan Alkohol Kronis

(Balinese Purple Sweet Potato (Ipomoea batatas L) on SGOT, SGPT, MDA level and Chronic Alcohol) I Wayan Putu Sutirta-Yasa, I Made Jawi, Ida Bagus Ngurah, Anak Agung Ngurah Subawa.

Leukosit Infeksi Bakteri Sistemik

(Leucocyte in Systemic Bacterial Infections)

Meita Hendrianingtyas, MI. Tjahjati DM

Meningitis Tuberculosis

(Meningitis Tuberculosis)

Silvia Rachmayati, Ida Parwati, A Rizal, D Oktavia

Platelet Aggregation In Acute Coronary Syndrome

(Aggregasi Trombosit di Sindroma Koroner Akut)

Sulianty, Adi K Aman..

TELAAH PUSTAKA

Pemetaan Epitop dan Aplikasi Klinisnya

(Epitope Mapping and It's Clinical Aplication)

Jusak Nugraha.

LAPORAN KASUS

Infeksi Virus Rabies di Anak-anak

(Rabies Virus Infection in Children)

A.A.N. Subawa, DGD. Dharma Santhi, A.A Raka Sudewi, IWP. Sutirta Yasa 


\title{
CREATINE KINASE MYOCARDIAL BAND, MYELOPEROXIDASE, MATRIX METALLOPROTEINASE-9 DAN TROPONIN T PADA IMA
}

\author{
(The Creatine Kinase Myocardial Band, Myeloperoxidase, Matrix Metalloproteinase- \\ 9 Activities and Troponin T in Myocardial Infarction)
}

IA Hutagalung ${ }^{1}$, I Patellongi ${ }^{2}$, R Pakasi ${ }^{1}$, M Arif ${ }^{1}$, AA Mappahya ${ }^{3}$, Hardjoeno ${ }^{1}$

\begin{abstract}
In many patients presenting with chest pain symptoms at the emergency room, cardiac markers are measured not only to detect acute myocardial infarction (AMI) but to exclude them too. Presently, the only biochemical markers used for diagnosis of MI are creatine kinase myocardial band (CKMB) and troponin $T(c T n T)$ as the markers of myocardial necrosis. Other biochemical markers have been sought to find marker which can reflect the important, upstream processes in the pathophysiology of MI that therefore might give an earlier signal of ongoing MI. These markers are myeloperoxidase (MPO) and matrix metalloproteinase-9 (MMP-9) as markers of plaque destabilization. The aim of this study was to analyze the CKMB, MPO, MMP-9 activityies and troponin T level in MI. A cross sectional study had been done at the Cardiovascular Centre Unit and Internal Ward of Dr. Wahidin Sudirohusodo Hospital during April up to August 2010 period. The laboratory tests were done at the Clinical Pathology Laboratory of Dr. Wahidin Sudirohusodo Hospital, Makassar and the Research and Esoteric Unit of Prodia Clinical Laboratory, Jakarta. Ffifty-three patients with AMI had been examined. The results showed that the means of CKMB, cTnT, MPO and MMP-9 were $52.4 \mathrm{U} / \mathrm{L}, 2.0 \mathrm{ng} / \mathrm{mL}, 217.9 \mathrm{ng} / \mathrm{mL}$ and $920.3 \mathrm{ng} / \mathrm{mL}$, respectively. MMP-9 had positively value (69.8\%) higher than cTnT (60.4\%), MPO (58.5\%) and CKMB (45.3\%). Troponin T and MMP-9 were higher in patients with high CKMB. The higher level of CKMB will be the higher MPO, MMP-9 and cTnT. There were strong correlation between MPO and MMP-9, also between CKMB and Troponin T. Troponin T and CKMB were lower in inferior wall infarction compared with anterolateral/anteroseptal wall infarction. The most sensitive biochemical marker in patients with AMI is the MMP-9. The MMP-9 usage is suggested to assist the diagnosis of AMI. It is suggested a further study to establish the specificity of MMP-9 in all patients suffering with chest pain.
\end{abstract}

Key words: Myocardial infarction, biochemical markers, CKMB, troponin T, MPO, MMP-9

\begin{abstract}
ABSTRAK
Pasien yang datang dengan nyeri dada di instalasi rawat darurat, biasanya diperiksa petanda jantungnya, bukan hanya untuk mendiagnosis IMA akut, tetapi juga untuk menyingkirkan keberadaan IMA. Petanda yang umum digunakan adalah CKMB dan cTnT, yaitu sebagai petanda kematian jaringan otot jantung (nekrosis miokard). Beberapa petanda lain yang telah ditemukan belakangan ini berhubungan dengan penyakit faali (patofisiologi) sebelum IMA terjadi, antara lain MPO dan MMP-9, sebagai petanda destabilisasi plak. Penelitian ini bertujuan untuk menganalisis kegiatan CKMB, MPO, MMP-9 dan kadar cTnT pada IMA akut. Penelitian dilakukan di Cardiovascular Center Unit (CVCU) dan Ruang Perawatan Penyakit Dalam RSUP Dr. Wahidin Sudirohusodo. Pemeriksaan laboratorik dilakukan di Instalasi Laboratorium Patologi Klinik RSUP dr. Wahidin Sudirohusodo, Makassar dan Unit Riset dan Esoterik Laboratorium Klinik Prodia Kramat, Jakarta. Penelitian bersifat potong silang (cross sectional) yang dilakukan selama masa waktu April-Agustus 2010. Hasil telitian terhadap 53 subjek IMA akut menunjukkan nilai tengah CKMB, cTnT, MPO dan MMP-9 berturut-turut adalah 52,4 U/L, 2,0 ng/mL, 217,9 ng/mL dan 920,3 ng/mL. Kadar MMP-9 memiliki nilai positif (69,8\%), lebih tinggi bila dibandingkan dengan cTnT (60,4\%), MPO (58,5\%) dan CKMB (45,3\%). Kadar cTnT dan MMP-9 lebih tinggi daripada penderita dengan CKMB yang tinggi. Semakin tinggi CKMB, semakin tinggi pula kadar MPO, MMP-9 dan cTnT. Kenasaban MPO dengan MMP-9, serta CKMB dengan cTnT adalah yang paling kuat. Kadar CKMB dan cTnT lebih rendah di jaringan mati bawah (infark inferior) daripada jaringan mati samping depan (infark anterolateral)/sekat depan (anteroseptal). Kepekaan MMP-9 tertinggi dibandingkan petanda lain, sehingga perlu dipertimbangkan penggunaan MMP-9 untuk membantu menetapkan diagnosis IMA akut. Disarankan meneliti lebih lanjut untuk menguji kekhasan MMP-9 di semua kasus dengan keluhan nyeri dada.
\end{abstract}

Kata kunci: IMA akut, CKMB, cTnT, MPO, MMP-9

1 Departemen Patologi Klinik, Fakultas Kedokteran, Univ. Hasanuddin J1. Perintis Kemerdekaan Tamalanrea, Makassar. Telp. 0411-581226. E-mail: dr_ingridhutagalung@yahoo.com

2 Departemen Fisiologi, Fakultas Kedokteran, Univ. Hasanuddin J1. Perintis Kemerdekaan Talamanrea, Makassar

3 Departemen Penyakit Dalam, Divisi Kardiovaskular, Fakultas Kedokteran, Univ. Hasanuddin Jl. Perintis Kemerdekaan Talamanrea, Makassar 


\section{PENDAHULUAN}

Setiap pasien yang datang dengan keluhan nyeri dada memerlukan diagnosis yang cepat dan teliti. ${ }^{1}$ Penegasan dan pengenalian adanya IMA adalah hal yang mendasar, karena berkaitan dengan penempatan dan perawatan pasien secara tepat. Tujuan diagnosis yang cepat dan teliti adalah agar segera dapat mengobati pasien IMA dengan intervensi yang tepat. ${ }^{2}$ Pengobatan trombolisis dan atau angioplasti koroner yang segera dilakukan untuk pasien IMA terbukti dapat menurunkan kesakitan dan kematian. ${ }^{1}$ Pengobatan trombolisis dalam satu jam pertama setelah serangan nyeri menurunkan kematian sampai 90\%, sedangkan pada 10-12 jam kemudian penurunan kematiannya menurun. ${ }^{3}$

IMA akut dibedakan antara non ST elevation myocardial infarction (non-STEMI) atau non- $Q$ wave dan STEMI atau $Q$ wave.4,5,6 Menurut WHO tahun 1979, diagnosis IMA didasarkan sehubungan ditemukannya dua (2) dari tiga (3) temuan yaitu: pertama, berupa anamnesis yang khas terkait gejala dan pemeriksaan fisik. Kedua, rekam jantung (elektrokardiografi) yang khas di dua (2) atau lebih peranan penting (lead) dan ketiga; diagnosis laboratorik yang peka dan khas. ${ }^{7,8}$

Patokan diagnosis ini mempunyai keterbatasan, karena banyak pasien didiagnosis salah sebagai IMA atau bukan IMA. ${ }^{3}$ Tidak semua pasien memang yang terbukti menderita IMA datang dengan patokan diagnostis yang jelas, terutama pada saat awal. Adakalanya gejala klinik tidak jelas, juga rekam jantung sebagian pasien tetap normal, serta petanda enzim jantung tidak khas. Banyak kejadian pasien dipulangkan, tetapi kemudian di rumah mendapatkan serangan IMA yang berakibat mematikan. ${ }^{9}$

Sejak tahun 1980-an diagnostik laboratorik baku untuk IMA adalah pemeriksaan pola enzim meliputi creatine kinase (CK) beserta isoenzimnya, yaitu creatine kinase myocardial band (CKMB) yang dianggap sebagai baku emas. Di samping itu ada juga enzim lain seperti aspartate transaminase (AST), lactate dehydrogenase ( $\mathrm{LDH}$ ) dan hydroxybutyrate dehydrogenase (HBDH). ${ }^{7}$ Apabila pasien datang pada jam atau saat awal serangan nyeri dada, maka ia dianjurkan memeriksakan jumlah keseluruhan CK dan CKMB. Bila pasien datang setelah lewat dua (2) hari, maka ia diperiksa LDH dan HBDH-nya. Semua enzim tersebut tidak khas untuk otot jantung (miokard), kecuali CKMB yang relatif khas untuk IMA, sehingga masih banyak keluhan peklinik terhadap pola enzim tersebut. 5,7

Sejak cardiac troponin $\mathrm{T}$ (cTnT) ditemukan pada tahun 1990-an, banyak telitian menunjukkan bahwa cTnT dianggap terbaik untuk diagnosis dan perlapisan kebahayaan (stratifikasi risiko), sehingga dijadikan baku emas baru, ${ }^{5}$ maka European Society of Cardiology
(ESC), American College of Cardiology (ACC) dan American Heart Association (AHA) menyatakan bahwa petanda tunggal IMA adalah cTnT. Diagnosis IMA mengalami perubahan terutama berdasarkan kenaikan kadar cTnT. ${ }^{10}$

Temuan cTnT tersebut membuat penggunaan enzim jantung yang sebelumnya menjadi kurang (tidak) dipakai lagi untuk menetapkan diagnosis IMA, tetapi dengan ditemukannya petanda baru untuk penyakit jantung koroner, maka diagnosis dapat dilakukan dengan cepat menggunakan pendekatan petanda ganda. ${ }^{7,11}$ Petanda baru tersebut antara lain myeloperoxidase (MPO), enzim tertentu yang tersimpan dalam granula azurofilik neutrofil dan makrofag. ${ }^{11}$ Di inflamasi, enzim tersebut dilepaskan ke peredaran darah dan berperan juga dalam oksidasi lipid dalam low density lipoprotein (LDL), sedangkan di IMA, stres oksidatif dan inflamasi berperan terhadap destabilisasi arteri koroner. ${ }^{12,13}$ Myeloperoxidase merupakan petanda ketidakstabilan plak walaupun tidak khas untuk penyakit jantung, tetapi merupakan penentu bebas (prediktor independen) yang kuat untuk gangguan fungsi endotel, jika dibandingkan dengan c-reactive protein (CRP) lebih kuat. ${ }^{14}$

Petanda IMA yang lain adalah matrix metalloproteinase-9 (MMP-9), yang akhir-akhir ini mendapatkan banyak perhatian untuk menganalisis pesusun (remodeling) vaskular karena digambarkan (ekspresikan) oleh sel otot polos dan leukosit serta berkemampuan merusak komponen membran basal dan kolagen. ${ }^{15}$ Pada penelitian oleh Blankenberg et al. disimpulkan, bahwa kadar MMP-9 digunakan sebagai peramalan kematian pasien penyakit jantung koroner (PJK) yang mengidap penyakit kardiovaskular. ${ }^{16}$ Matrix Metalloproteinase-9 juga terlibat dalam beberapa tahapan pengerasan buluh arteri (ateriosklerosis). ${ }^{9}$ Degradasi matriks merupakan prasyarat pembaharuan monosit karena perpindahan leukosit yang melewati endotelium mengharuskan ada kerusakan di membran dasar. ${ }^{17}$ Beberapa tahun terakhir ini telah dilakukan banyak penelitian untuk mengetahui peran lain MMP-9. Galis dan Khatri menunjukkan keterkaitan antara MMP-9 dengan ketidakstabilan plak. ${ }^{15}$ Berdasarkan telitian Brown, dapat ditunjukkan bahwa sintesis MMP-9 oleh makrofag dan sel otot polos dilakukan secara aktif dalam ateroma jantung pasien dengan angina tidak stabil. ${ }^{18}$ Shah membuktikan secara ex vivo kemampuan makrofag dalam mengimbas kolagen dalam tudung jaringan ikat (fibrous cap) dari endapan lemak luar sel (aterom) melalui MMP. ${ }^{19}$

Berdasarkan penelitian tinjauan ke belakang (retrospektif) yang dilakukan Hong dengan menggunakan three-vessel intravascular ultrasound, didapatkan bahwa kekoyakan plak terjadi baik tunggal maupun lebih dari satu lebih umum dijumpai 
di pasien infark jantung dibandingkan dengan pasien angina stabil. Kekoyakan plak juga lebih umum dijumpai di infark jantung dengan peningkatan bagian ST. ${ }^{20}$

Kedua petanda baru ini, MPO dan MMP-9, merupakan petanda penting untuk ketidakstabilan plak. ${ }^{9}$ Beberapa penelitian yang telah dilakukan untuk membuktikan bahwa dengan pendekatan diagnosis menggunakan petanda ganda di IMA, lebih baik bila dibandingkan dengan petanda tunggal. Apple et al. dan Apple et al. membuktikan bahwa strategi antara lain menggunakan petanda ganda dengan $C K M B$, kadar $c T n$, khususnya troponin $T$ ( $(T n T), M P O$ dan $M M P-9$, dapat meningkatkan kepekaan dan kekhasan dalam mendiagnosis IMA. ${ }^{21,22}$

Penelitian peranan $C K M B, c T n T, M P O$ dan MMP-9 dalam patogenesis IMA sudah banyak dilakukan di negara lain, tetapi di Indonesia relatif masih kurang. Berdasarkan uraian di atas, maka dapat dirumuskan masalah penelitian sebagai berikut: Apakah MPO dan MMP-9 dapat dijadikan petanda baru IMA?

Tujuan penelitian ini adalah menganalisis kegiatan $C K M B, M P O, M M P-9$ dan kadar $C T n T$ pada IMA. Manfaat penelitian ini adalah mengupayakan tambahan dugaan tolok ukur baru yaitu MPO dan MMP-9 dalam menetapkan diagnosis IMA tahap dini, sehingga lebih cepat diobati dan diharapkan mengurangi kematian dan kekerapan rawat ulang. Stratifikasi kebahayaan IMA dan hasil telitian dapat digunakan sebagai dasar penelitian lebih lanjut segi patofisiologi IMA.

\section{METODE}

Penelitian bersifat kajian amatan (observasional) dengan pendekatan cross sectional selama masa waktu April 2010 sampai Agustus 2010. Tempat penelitian di Cardiovascular Care Unit (CVCU) dan Perawatan Penyakit Dalam Rumah Sakit Umum Pusat (RSUP) BLU Dr. Wahidin Sudirohusodo Makassar.

Populasi pada penelitian adalah penderita IMA yang menjalani perawatan di CVCU dan Perawatan Penyakit Dalam RSUP BLU Dr. Wahidin Sudirohusodo Makassar. Patokan kesertaan adalah orang dewasa yang datang ke CVCU BLU RSUP Dr. Wahidin Sudirohusodo. Setelah dilakukan pemeriksaan fisik, EKG dan laboratorik ( $C K M B$ dan $c T n T$ ) dan ia dinyatakan sebagai penderita IMA. Kemudian ia menyatakan persetujuan bersedia ikut dalam penelitian dengan mengisi dan menandatangani lembar surat persetujuan tindakan. Patokan ketidaksertaan adalah penderita dengan IMA yang disertai adanya jejas di jantung selain yang disebabkan oleh IMA, yaitu bila terdapat jejas, seperti: radang otot jantung (miokarditis), penyakit otot jantung (kardiomiopati), gagal jantung kongestif, emboli paru, trauma dada dan radang endokardium (endokarditis). Demikian pula jika ada infeksi yang ditandai dengan demam dan jumlah leukosit yang lebih dari 10.000/dL, serta ada keganasan atau strok.

Pengambilan spesimen dilakukan di CVCU dan Perawatan Penyakit Dalam RSUP BLU Dr. Wahidin Sudirohusodo Makassar dari sampel yang telah memenuhi patokan kesertaan.

Uji laboratorik dilakukan di Instalasi Laboratorium Patologi Klinik BLU RSUP Dr. Wahidin Sudirohusodo untuk uji $C K M B$ dan $c T n T$, sedangkan untuk uji $M P O$ dan MMP-9 di Unit Riset \& Esoterik Laboratorium Klinik Prodia Kramat, Jakarta. Uji CKMB menggunakan serum dan memakai alat ABX Pentra 400 (France) dengan metode immunochemistry, nilai rujukan $<25 \mathrm{U} / \mathrm{L}^{23} \mathrm{Uji} c \mathrm{Tn} T$ menggunakan pemeriksaan heparin darah lengkap memakai alat Roche Cardiac Troponin T Quantitative Cardiac Reader (Germany) berdasarkan prinsip ELISA, nilai rujukan $<0,1 \mathrm{ng} / \mathrm{mL} .{ }^{24}$ Tes $M P O$ menggunakan serum dan memakai alat MPO Quantikine buatan R\&D Systems (Minneapolis), nomor lot DMYEOO 269895 dengan cara EIA berdasarkan prinsip ELISA, nilai rujukan 209-1799 ng/mL. ${ }^{25}$ Uji MMP-9 menggunakan serum dan memakai alat MMP-9 Quantikine R\&D Systems (Minneapolis), nomor lot DMP 900260737 dengan cara EIA berdasarkan prinsip ELISA, nilai rujukan $169-705 \mathrm{ng} / \mathrm{mL}^{26}$

\section{HASIL DAN PEMBAHASAN}

Penelitian dilakukan selama masa waktu April sampai Agustus 2010, diperoleh 53 sampel penelitian penderita IMA yang telah memenuhi patokan kesertaan dan ketidaksertaan, terdiri atas 38 orang $(71,7 \%)$ laki-laki dan 15 orang $(38,3 \%)$ perempuan, berumur antara 17-84 tahun dengan rerata 55,9

Tabel 1. Hasil analisis deskriptif $C K M B, c T n T, M P O$ dan $M M P-9$ penderita IMA

\begin{tabular}{|c|c|c|c|c|}
\hline \multirow{2}{*}{$\begin{array}{l}\text { Variabel } \\
\text { (satuan) }\end{array}$} & \multicolumn{2}{|c|}{ Statistik deskriptif } & \multirow{2}{*}{ Nilai rujukan } & \multirow{2}{*}{$\frac{\text { Abnormal }}{\text { n (\%) }}$} \\
\hline & Min-Max & Median & & \\
\hline CKMB (U/L) & $4,0-869,7$ & 52,4 & $<25$ & $24(45,3 \%)$ \\
\hline$c T n T$ (ng/mL) & 0,09 & 2,0 & $<0,1$ & $32(60,4 \%)$ \\
\hline$M P O(\mathrm{ng} / \mathrm{mL})$ & $181,8-4920,8$ & 217,9 & 209-1799 & $31(58,5 \%)$ \\
\hline$M M P-9(\mathrm{ng} / \mathrm{mL})$ & $123,4-1879,5$ & 920,3 & 169-705 & $37(69,8 \%)$ \\
\hline
\end{tabular}


tahun. Analisis pemerian (deskriptif) menunjukkan bahwa penderita IMA laki-laki lebih banyak daripada perempuan yaitu berturut-turut $71,7 \%$ dan $28,3 \%$. Kelompok umur yang paling banyak adalah 55-64 tahun yaitu 34,0\% dari 53 sampel dan disusul kelompok umur 45-54 tahun.

Tabel 1 memperlihatkan bahwa kegiatan $C K M B$, kadar cTnT, MPO dan MMP-9 menunjukkan nilai yang lebih tinggi daripada nilai rujukan dan berturutturut $69,8 \%$ penderita mengalami peningkatan MMP-9, 60,4\% mengalami peningkatan cTnT, 58,5\% mengalami peningkatan $M P O$ dan 45,3\% mengalami peningkatan $C K M B$.

Berdasarkan hasil telitian di Tabel 1, MMP-9 memiliki nilai kepositifan tertinggi dibandingkan petanda lainnya, maka di Tabel 2 berikut ini diperlihatkan hasil analisis deskriptif $M M P-9$ berdasarkan golongan $C K M B$ normal dan $C K M B$ yang meningkat.

Tabel 2. Hasil analisis deskriptif $M M P-9$ berdasarkan pengelompokan $C K M B$

\begin{tabular}{lccc}
\hline \multirow{2}{*}{ Kegiatan petanda } & \multicolumn{2}{c}{ MMP-9 } \\
\cline { 3 - 4 } & & Tinggi & Normal \\
\hline \multirow{2}{*}{$C K M B$} & Tinggi & $22(41,5 \%)$ & $2(3,8 \%)$ \\
& Normal & $15(28,3 \%)$ & $14(26,4 \%)$ \\
\hline
\end{tabular}

Tabel 2 memperlihatkan bahwa sebanyak 22 orang (41,5\%) penderita memiliki hasil baik CKMB maupun MMP-9 yang meningkat dan sebanyak 15 orang $(28,3 \%)$ penderita memiliki hasil $C K M B$ yang normal tetapi kegiatan $M M P-9$ mengalami peningkatan.
Bila dikelompokkan penderita menurut $C K M B$, diperoleh 24 orang telah mengalami peningkatan $C K M B$, yaitu lebih tinggi daripada nilai normalnya, sedangkan 29 orang masih dalam batas normal. Hasil analisis perbedaan kadar $c T n T, M P O$ dan MMP-9 berdasarkan pengelompokan $C K M B$ dapat dilihat di Tabel 3.

Tabel 3. Perbedaan kadar cTnT, MPO dan MMP-9 berdasarkan pengelompokan CKMB

\begin{tabular}{lccc}
\hline Variabel (satuan) & \multicolumn{2}{c}{ CKMB } & Uji Mann \\
\cline { 2 - 3 } & Tinggi & Normal & Whitney \\
\hline$c T n T(\mathrm{ng} / \mathrm{mL})$ & 0,74 & 0,21 & 0,000 \\
$M P O(\mathrm{ng} / \mathrm{mL})$ & 2527,4 & 1938,7 & 0,086 \\
$M M P-9(\mathrm{ng} / \mathrm{mL})$ & 1130,8 & 780,0 & 0,022 \\
\hline
\end{tabular}

Tabel 3 menunjukkan bahwa kadar cTnT dan MMP-9 lebih tinggi secara bermakna di kelompok $C K M B$ daripada bila kelompok $C K M B$ normal. Kadar $M P O$ juga lebih tinggi di kelompok CKMB yang tinggi, tetapi belum bermakna secara statistik $(\mathrm{p}=0,086)$.

Hasil analisis kenasaban antara CKMB, cTnT, MPO dan MMP-9 dapat dilihat di Tabel 4.

Tabel 4 menunjukkan bahwa ditemukan kenasaban linier positif yang bermakna $(\mathrm{p}<0,05)$ antara CKMB dengan MPO (kenasaban lemah), MMP-9 (kenasaban lemah) dan cTnT (kenasaban sedang). Semakin tinggi kadar $C K M B$, semakin tinggi kadar $M P O, M M P-9$ dan $c T n T$. Kenasaban CKMB dengan $c T n T$ lebih kuat ( $\mathrm{r}=0,57)$ daripada kenasaban $C K M B$ dengan $M M P-9$ $(\mathrm{r}=0,48)$ maupun kenasaban $C K M B$ dengan $M P O$ $(r=0,32)$.

Tabel 4. Analisis kenasaban antara $C K M B, c T n T, M P O$ dan $M M P-9$

\begin{tabular}{lllll}
\hline Variabel & CKMB & MPO & MMP-9 & \multicolumn{1}{c}{ cTnT } \\
\hline CKMB & $\mathrm{r}=1,00$ & $\mathrm{r}=0,32$ & $\mathrm{r}=0,48$ & $\mathrm{r}=0,57$ \\
& & $\mathrm{p}=0,034$ & $\mathrm{p}=0,001$ & $\mathrm{p}=0,000$ \\
MPO & $\mathrm{r}=0,32$ & $\mathrm{r}=1,00$ & $\mathrm{r}=0,72$ & $\mathrm{r}=0,30$ \\
& $\mathrm{p}=0,034$ & & $\mathrm{p}=0,000$ & $\mathrm{p}=0,068$ \\
MMP-9 & $\mathrm{r}=0,48$ & $\mathrm{r}=0,72$ & $\mathrm{r}=1,00$ & $\mathrm{r}=0,33$ \\
& $\mathrm{p}=0,001$ & $\mathrm{p}=0,000$ & & $\mathrm{p}=0,042$ \\
cTnT & $\mathrm{r}=0,57$ & $\mathrm{r}=0,30$ & $\mathrm{r}=0,33$ & $\mathrm{r}=1,00$ \\
& $\mathrm{p}=0,000$ & $\mathrm{p}=0,068$ & $\mathrm{p}=0,042$ & \\
\hline
\end{tabular}

Tabel 5. Analisis perbedaan kadar $C K M B, c T n T$, $M P O$ dan $M M P-9$ berdasarkan lokasi infark

\begin{tabular}{llcccc}
\hline Variabel & \multicolumn{1}{c}{ Lokasi infark) } & n & Rerata (mean) & SD & $\begin{array}{c}\text { Uji Mann } \\
\text { Whitney }\end{array}$ \\
\hline CKMB & Bawah (inferior) & 13 & 16,3654 & 14,2014 & $\mathrm{p}=0,004$ \\
& anterolateral/anteroseptal & 40 & 64,1772 & 142,972 & \\
\multirow{2}{*}{ TnT } & 13 & 0,1262 & 0,7478 & $\mathrm{p}=0,001$ \\
& inferior & 40 & 0,9155 & 0,93485 & \\
\multirow{2}{*}{ MPO } & anterolateral/anteroseptal & 12 & 1905,1 & 1738,28 & $\mathrm{p}=0,257$ \\
& inferior & 32 & 2284,2 & 1326,55 & \\
& anterolateral/anteroseptal & 12 & 723,75 & 543,397 & $\mathrm{p}=0,088$ \\
& inferior & 33 & 991,83 & 461,661 & \\
\hline
\end{tabular}


Tabel 4 juga menunjukkan bahwa ditemukan kenasaban linier positif yang bermakna $(p<0,05)$ antara $M P O$ dengan $M M P-9$ (kenasaban agak kuat) dan $c T n T$ (kenasaban lemah), begitu pula antara MMP-9 dengan cTnT (kenasaban lemah), yaitu kenasaban antara MMP-9 dengan $M P O$ menunjukkan kenasaban yang paling kuat $(r=0,72)$ di antara hasil analisis kenasaban lainnya.

Hasil analisis perbedaan kadar CKMB, cTnT, MPO dan $M M P-9$ berdasarkan lokasi infark dapat dilihat di Tabel 5.

Tabel 5 menunjukkan bahwa perbedaan yang bermakna $(\mathrm{p}<0,05)$ ditemukan di kadar $C K M B$ dan cTnT. Kadar CKMB dan cTnT lebih rendah di kadar infark inferior daripada infark anterolateral/ anteroseptal. Rerata kadar CKMB di infark inferior 16,37 U/L, sedangkan di infark anterolateral/ anteroseptal 64,18 U/L dan rerata $c T n T$ infark inferior $0,1 \mathrm{ng} / \mathrm{mL}$, dan di infark anterolateral/anteroseptal $0,9 \mathrm{ng} / \mathrm{mL}$.

Kadar MPO dan MMP-9 walaupun cenderung lebih rendah di infark inferior daripada infark anterolateral/anteroseptal, tetapi tidak bermakna secara statistik ( $\mathrm{p}>0,05)$.

Tabel 6 menunjukkan bahwa lokasi infark terbanyak adalah anterolateral/ anteroseptal dibandingkan dengan yang inferior. Peningkatan kadar keempat petanda ditemukan lebih banyak di infark anterolateral/anteroseptal dan didapatkan berturut-turut MMP-9 meningkat di 31 orang penderita (77,5\%), cTnT 29 orang (72,5\%), MPO 26 orang (65,0\%) dan CKMB 22 orang (55,0\%).

Pada penelitian ini didapatkan bahwa penderita laki-laki lebih banyak daripada perempuan yaitu $71,7 \%$ dari 53 penderita, sesuai dengan yang dilaporkan oleh Elsaesser dan Hamm bahwa penderita IMA perempuan kurang dari 40\%. ${ }^{27}$ Dan kelompok umur yang terbanyak adalah 55-64 tahun yaitu $34,0 \%$ dan disusul kelompok umur 45-54 tahun sebanyak 26,4\%. Hal tersebut sesuai dengan survey yang telah dilakukan oleh Boedhi dkk pada tahun 1995, bahwa kelompok umur di atas 55 tahun sebesar 36,5\%.28 Kedua faktor tersebut, yaitu umur dan jenis kelamin, termasuk dalam faktor kebahayaan yang tidak dapat diubah untuk terjadi aterosklerosis. Kerentanan terhadap aterosklerosis koroner meningkat dengan bertambahnya umur. Kejadian yang parah jarang sebelum usia 40 tahun dan perempuan relatif jarang mengalami aterosklerosis sampai berhenti haid (menopause), hal ini diduga berhubungan erat dengan hormon estrogen. ${ }^{29}$

Analisis deskriptif hasil meneliti didapatkan bahwa di antara 53 penderita, sebanyak 69,8\% mengalami peningkatan MMP-9, 60,4\% mengalami peningkatan cTnT, 58,5\% mengalami peningkatan MPO dan 45,3\% mengalami peningkatan CKMB. Hasil meneliti ini menunjukkan bahwa dibandingkan dengan ketiga variabel yang lain, $M M P-9$ memiliki derajat positif yang paling tinggi, disusul oleh cTnT dan $M P O$. Dalam hal ini $C K M B$ memiliki kepositifan yang paling rendah. Kai dkk juga melaporkan bahwa $M M P-9$ secara bermakna meningkat dua sampai tiga kali lipat pada hari pertama sampai hari ketiga bila dibandingkan dengan kontrol. ${ }^{30}$ Pada penelitian ini spesimen diambil kurang dari 24 jam setelah penderita masuk rumah sakit. Blankenberg dkk, melaporkan bahwa kadar MMP-9 meningkat secara bermakna di penderita kardiovaskuler bila dibandingkan dengan kontrol. ${ }^{16} \mathrm{Hal}$ ini membuktikan bahwa MMP-9 sebagai petanda ketidakstabilan plak, merupakan petanda yang memiliki nilai kepositifan yang paling tinggi bila dibandingkan dengan $c T n T$, $M P O$ dan $C K M B$. Hal ini dapat dijelaskan karena MMP-9 yang disekresikan oleh sel otot polos pembuluh darah, yang akan menghancurkan kolagen fibrous cap ateroma di penderita IMA. ${ }^{16}$ Hasil meneliti ini juga menunjukkan bahwa kepositifan $C K M B$ paling rendah dibandingkan dengan petanda lain, yaitu hanya $45,3 \%$, berarti sebanyak $54,7 \%$ pasien IMA dalam penelitian ini memiliki $C K M B$ yang negatif. Hal ini membuktikan bahwa CKMB yang negatif tidak menyingkirkan keberadaan IMA.

Pada penelitian ini dikelompokkan $C K M B$ berdasarkan $C K M B$ normal dan $C K M B$ yang meningkat, karena $C K M B$ masih dipakai sebagai salah satu petanda enzimatik IMA. Hal ini dilakukan untuk melihat perbedaan kadar variabel lain berdasarkan pengelompokan $C K M B$ normal dan $C K M B$ yang tinggi. Winter dkk meneliti pada tahun 1995 untuk melihat hubungan beberapa petanda IMA (myoglobin dan $c T n T$ ) dengan keluasan infark berdasarkan pengelompokan CKMB. ${ }^{31}$

Berdasarkan penjelasan sebelumnya, bahwa bila dibandingkan dengan ketiga variabel yang lain, MMP-9 memiliki kepositifan yang paling tinggi, maka dibuat analisis deskriptif MMP-9 tertentu berdasarkan

Tabel 6. Hasil analisis deskriptif penderita dengan kadar CKMB, cTnT, MPO dan MMP-9 tinggi dan normal berdasarkan lokasi infark

\begin{tabular}{|c|c|c|c|c|c|c|c|c|}
\hline \multirow{2}{*}{ Lokasi infark } & \multicolumn{2}{|c|}{ CKMB } & \multicolumn{2}{|c|}{ cTnT } & \multicolumn{2}{|c|}{ MPO } & \multicolumn{2}{|c|}{ MMP-9 } \\
\hline & Tinggi & Normal & Tinggi & Normal & Tinggi & Normal & Tinggi & Normal \\
\hline $\begin{array}{l}\text { Anterolateral/ } \\
\text { anteroseptal }\end{array}$ & $22(55,0 \%)$ & $18(45,0 \%)$ & $29(72,5 \%)$ & $11(27,5 \%)$ & $26(65,0 \%)$ & $14(35,0 \%)$ & $31(77,5 \%)$ & $9(22,5 \%)$ \\
\hline Inferior & $2(15,4 \%)$ & $11(84,6 \%)$ & $3(23,1 \%)$ & $10(76,9 \%)$ & $5(38,5 \%)$ & $8(61,5 \%)$ & $6(46,2 \%)$ & $7(53,8 \%)$ \\
\hline
\end{tabular}


kegiatan $C K M B$ yang normal dan meningkat. Hasil analisis memperlihatkan bahwa sebanyak 22 orang $(41,5 \%)$ penderita memiliki hasil baik $C K M B$ maupun $M M P-9$ yang meningkat. Analisis ini juga menunjukkan bahwa sebanyak 15 orang $(28,3 \%)$ penderita atau hampir sepertiga penderita mengalami peningkatan kegiatan MMP-9 walaupun CKMB masih dalam batas normal. Hal ini membuktikan bahwa infark tidak selalu diikuti dengan peningkatan $C K M B$. Jadi bila gejala klinik penderita sangat mendukung keberadaan IMA, bila kegiatan $C K M B$ dalam batas normal. Pemeriksaan dilanjutkan untuk mengetahui aktivitas MMP-9 karena keadaan tersebut bukan petanda khas kerusakan otot jantung, tetapi merupakan petanda sumbatan plak yang robek (rupture). Jadi keberadaan ruptur plak, kegiatan $M M P-9$ jadi meningkat.

Hasil telitian ini juga menunjukkan bahwa kadar cTnT dan MMP-9 lebih tinggi secara bermakna di kelompok $C K M B$ yang tinggi daripada kelompok CKMB yang normal. Kadar MPO juga lebih tinggi, tetapi secara statistik tidak bermakna. Winter dkk juga melaporkan bahwa terjadi peningkatan $c T n T$ yang bermakna di penderita dengan $C K M B$ yang tinggi. ${ }^{31}$

Penelitian ini juga menganalisis kenasaban antara keempat variabel, yaitu $C K M B, c T n T, M P O$ dan $M M P$ 9. Hasil analisis menunjukkan bahwa ditemukan kenasaban linier positif yang bermakna antara keempat variabel tersebut. Semakin tinggi kadar $C K M B$, semakin tinggi pula kadar MPO, MMP-9 dan $c T n T$. Winter dkk juga melaporkan bahwa terjadi peningkatan kadar $c \operatorname{Tn} T$ bila $C K M B$ meningkat, ${ }^{31}$ tetapi sejauh ini belum ada laporan penelitian yang berhubungan dengan $C K M B$ yang meningkat dan terkait dengan kadar MPO dan MMP-9.

Analisis kenasaban keempat variabel ini juga menunjukkan bahwa kenasaban CKMB dan $C T n T$ lebih kuat dibandingkan dengan kenasaban $C K M B$ dan $M M P-9$ maupun $M P O$. Hal ini disebabkan CKMB dan cTnT dilepaskan ke dalam peredaran darah oleh otot jantung yang mengalami infark. ${ }^{32}$ Kenasaban antara $M M P-9$ dengan $M P O$ juga menunjukkan kenasaban yang lebih kuat, dibandingkan dengan kenasaban antara MMP-9 dengan cTnT. Hal ini disebabkan MMP9 dan $M P O$ merupakan petanda ketidakstabilan plak, walaupun MPO lebih kuat menjadi peramal bebas untuk gangguan fungsi endotel. ${ }^{14}$

Pada penelitian dianalisis beda kadar CKMB, $c T n T, M P O$ dan MMP-9 berdasarkan lokasi infark. Hasil meneliti menunjukkan perbedaan yang bermakna antara kadar CKMB dan $c T n T$. Kadar CKMB lebih rendah di infark inferior daripada infark anterolateral/anteroseptal, begitu pula dengan kadar $c T n T$. Hasil analisis deskriptif juga menunjukkan bahwa lokasi infark terbanyak di anterolateral/ anteroseptal. Peningkatan kadar keempat petanda ditemukan terbanyak di infark anterolateral/ anteroseptal dibandingkan dengan infark inferior dan yang didapatkan meningkat terbanyak adalah kegiatan MMP-9. Stone dkk, melaporkan bahwa ada hubungan antara $C K M B$ dengan lokasi infark. Lokasi infark inferior lebih sering terjadi di penderita dengan $C K M B$ yang lebih tinggi. Beberapa telitian menunjukkan bahwa lokasi infark tidak berhubungan dengan peramalan perjalanan penyakit penderita. ${ }^{33}$ Hasan dkk, melaporkan bahwa tidak ada hubungan yang bermakna antara lokasi infark dengan $c T n T$ penderita IMA di RSUP Adam Malik. ${ }^{34}$ Pada penelitian ini, peningkatan semua petanda didapatkan terbanyak di infark anterolateral/anteroseptal, kemungkinan berhubungan dengan letak anatomis arteri koronaria yang mendarahi bagian jantung yang letaknya di bawah dan ukurannya lebih kecil, sehingga untuk kembali ke sirkulasi umum lebih lambat. Sejauh ini belum ada penelitian yang melaporkan hubungan MPO dan MMP-9 dengan lokasi infark.

Namun penelitian ini terdapat keterbatasan, yaitu: pertama, waktu pengambilan spesimen darah penderita tidak disesuaikan dengan terjadinya serangan nyeri dada atau infark, hanya dibatasi sebelum lebih dari 24 jam setelah penderita masuk rumah sakit. Kedua, pada penelitian ini kegiatan $M P O$ dan $M M P-9$ dibandingkan dengan yang di $C K M B$, tetapi tidak dibandingkan dengan kadar cTnT yang selama ini telah dipakai sebagai baku emas petanda IMA. Ketiga, penelitian ini tidak mengukur lama waktu peningkatan MMP-9. Keterbatasan keempat adalah penelitian ini bukan merupakan uji diagnostik, sehingga yang didapatkan hanya derajat positif atau kepekaan setiap petanda yang diukur.

\section{SIMPULAN DAN SARAN}

Kepekaan tertinggi penderita IMA pada penelitian ini berturut-turut adalah $M M P-9, c T n T, M P O$ dan $C K M B$, dan ditemukan perbedaan yang bermakna antara kadar $c T n T, M P O$ dan MMP-9 berdasarkan pengelompokan CKMB. Kadar cTnT dan MMP-9 lebih tinggi di penderita dengan $C K M B$ yang tinggi, Ditemukan kenasaban gemaris (linier) positif yang bermakna antara $C K M B, M P O, M M P-9$ dan $c T n T$. Semakin tinggi kadar $C K M B$, semakin tinggi juga keadaan MPO, MMP-9 dan $c T n T$. Kenasaban MPO dan $M M P-9$ yang paling kuat setelah itu disusul kenasaban $C K M B$ dengan $c T n T$, ditemukan perbedaan yang bermakna di kadar $C K M B$ dan $c T n T$ berdasarkan lokasi infark. Kadar CKMB dan $c T n T$ lebih rendah di infark inferior daripada anterolateral anteroseptal. Kepekaan MMP-9 paling tinggi dibandingkan dengan petanda lain, sehingga sebaiknya dipertimbangkan penggunaan MMP-9 untuk membantu menetapkan diagnosis di penderita dengan kasus IMA terutama 
bila belum terjadi peningkatan kegiatan CKMB. Didasari telitian ini disarankan meneliti lebih lanjut untuk menguji kekhasan MMP-9 di semua kasus nyeri dada (kardiak infark, kardiak bukan infark, dan bukan kardiak).

\section{DAFTAR PUSTAKA}

1. Patel NR, Jackson G. Serum Markers in Myocardial Infarction. J Clin Pathol, 1999; 52: 409-10.

2. Mair J, Puschendorf B, Michel G. Clinical Significance of Cardiac Contractile Proteins for the Diagnosis of Myocardial Injury. Advances in Clin Chem, 1994; 5: 63-98.

3. Gavaghan, M. Biochemical Markers in Myocardial Injury. AORN Journal, 1999; 70: 840-50.

4. Smith SW, Whitwam, W. Acute Coronary Syndromes. Emerg Med Clin N Am, 2006; 24: 53-89.

5. Morrow DA, Cannon CP, Jesse, RL, et al. National Academy of Clinical Biochemistry Laboratory Medicine Practice Guidelines: Clinical Characterisrics and Utilization of Biochemical Markers in Acute Coronary Syndromes. Clin Chem, 2007; 53(4): 552-74.

6. Armstrong EJ, Morrow DA, Sabatine MS. Inflammatory Biomarkers in Acute Coronary Syndromes, Part I: Introduction and Cytokines. Circulation, 2006; 113: 72-75.

7. Achar SA, Kundu S, Norcross WA. Diagnosis of Acute Coronary Syndrome. Am Fam Physician, 2005; 72: 119-26.

8. World Health Organization. Nomenclature and Criteria for Diagnosis of Ischemic Heart Disease. Report of the Joint International Society and Federation of Cardiology/World Health Organization Task Force on Standardization of Clinical Nomenclature. Circulation, 1979; 59: 607-9.

9. Apple FS, Wu AH, Mair J, et al. Future Bimarkers for Detection of Ischemia and Risk Stratification in Acute Coronary Syndrome. Clin Chem, 2005; 51(5): 810-24.

10. Apple FS, Smith SW, Pearce LA, et al. Use of the Centaur TnIUltra Assay for Detection of Myocardial Infarction and Adverse Events in Patients Presenting with Symptoms Suggestive of Acute Coronary Syndrome. Clin Chem, 2008; 54(4): 723-8.

11. Morrow DA, Sabatine MS, Brennan, ML, et al. Concurrent Evaluation of Novel Cardiac Biomarkers in Acute Coronary Syndrome: Myeloperoxidase and Soluble CD40 Ligand and the Risk of Recurrent Ischaemic Events in TACTICS-TIMI 18. Eur Heart J, 2008; 29: 1096-1102.

12. Loria V, Dato I, Graziani F, et al. Myeloperoxidase: a New Biomarker of Inflammation in Ischemic Heart Disease and Acute Coronary Syndromes. Mediators of Inflammation, 2008; Article ID 135625: 1-4.

13. Singh U, Devaraj S, Jialal I. C-Reactive Protein Stimulates Myeloperoxidase Release from Polymorphonuclear Cells and Monocytes: Implication for Acute Coronary Syndromes. Clin Chem, 2009; 55(2): 361-4.

14. Schindhelm RK, Zwan van der, Teerlink T, et al. Myelopreoxidase: a Useful Biomarker for Cardiovascular Disease Risk Stratification? Clin Chem, 2009; 55(8): 1462-70.

15. Galis ZS, Khatri JJ. Matrix Metalloproteinases in Vascular Remodeling and Atherogenesis, the Good, the Bad, and the Ugly. Circ Res, 2002; 90: 251-62.
16. Blankenberg S, Rupprecht HJ, Poirier OD, et al. Plasma Concentration and Genetic Variation of Matrix Metalloproteinase 9 and Prognosis of Patients with Cardiovascular Disease. Circulation, 2003; 107: 1579-85.

17. Jones CB, Sane DC, Herrington DM. Matrix Metalloproteinases: A Review of Their Structure and Role in Acute Coronary Syndrome. Cardiovasc Res, 2003; 59: 812-23.

18. Brown DL, Hibbs MS, Kearney M, et al. Identification of 92kD Gelatinase in Human Coronary Atherosclerotic Lessions: Association of Active Enzyme Synthesis with Unstable Angina. Circulation, 1995; 91: 2125-31.

19. Shah P, Falk E, Badimon J, et al. Human Monocyte-Derived Macrophages Induce Collagen Breakdown in Fibrous Caps of Atherosclerotic Plaques: Potential Role of Matrix-Degrading Metalloproteinases and Implications for Plaque Rupture. Circulation, 1995; 92(6): 1565-9.

20. Hong MK, Mintz GS, Lee CW, et al. Comparison of Coronary Plaque Rupture Between Stable Angina and Acute Myocardial Infarction: A Three-Vessel Intravascular Ultrasound Study in 235 Patients. Circulation, 2004; 110: 928-33.

21. Apple FS, Pearce LA, Chung A, Ler R, et al. Multiple Biomarker Use for Detection of Adverse Events in Patients Presenting with Symptoms Suggestive of Acute Coronary Syndrome. Clin Chem, 2007; 53(5): 874-81.

22. Apple FS, Smith SW, Pearce LA, et al. Assessment of the Multiple-Biomarker Approach for Diagnosis of Myocardial Infarction in Patients Presenting with Symptoms Suggestive of Acute Coronary Syndrome. Clin Chem, 2009; 55(1): 93-100.

23. Horiba ABX Pentra 400. Kit Insert ABX Pentra 400. Horiba ABX Diagnostics (France). 2010.

24. Roche Cardiac. Kit Roche CARDIAC Troponin T Quantitative. Roche Diagnostics (Germany). Catalog No. 11894307193. 2010.

25. R\&D Systems MPO. Kit MPO Quantikine. R\&D Systems (Minneapolis, USA). Catalog No. DMYE00. 2007.

26. R\&D Systems MMP-9. Kit MMP-9 Quantikine. R\&D Systems (Minneapolis, USA). Catalog No. DMP900. 2007.

27. Elsaesser A, Hamm CW. Acute Coronary Syndrome: The Risk of Being Female. Circulation, 2004; 109: 565-7.

28. Boedhi DR. Epidemiologi Penyakit Jantung Koroner. Semarang, Citra Utama, 2000. 8-10.

29. Falk E. Pathogenesis of Atherosclerosis. J Am Coll Cardiol, 2006; 47(8): C7-C12.

30. Kai H, Ikeda H, Yasukawa H, et al. Peripheral Blood Levels of Matrix Metalloproteases-2 and -9 are Elevated in Patients with Acute Coronary Syndromes. J Am Coll Cardiol, 1998. 32: 368-72.

31. Winter RJ, Koster RW, Sturk A, Sanders G. Value of Myoglobin, Troponin T, and CKMB mass in Ruling Out an Acute Myocardial Infarction in the Emergency Room. Circulation, 1995; 92: 3401-7.

32. Archan S, Fleisher LA. From Creatine Kinase-MB to Troponin. Anesthesiology, 2010; 112: 1005-12.

33. Stone PH, Raabe DS, Jaffe AS, et al. Prognostic Signoficance of Location and Type of Myocardial Infarction: Independent Adverse Outcome Associated with Anterior Location. J Am Coll Cardiol, 1988; 11: 453-63.

34. Hasan H, Tarigan E. Hubungan Kadar Troponin T dengan Gambaran Klinis Penderita Sindroma Koroner Akut. Majalah Kedokteran Nusantara, 2005; 38(4): 286-90. 